\title{
Synthesis and Anticonvulsant Activity of Certain
}

\section{$\underline{N-A r a l k y l-N-(1-S u b s t i t u t e d ~ C y c l o h e x y l) ~ B e n z e n a m i n e s ~}$}

\section{Nabil Aboul-Enein ${ }^{* 1}$, Aida El-Azzouny ${ }^{1}$, Fatma Ragab ${ }^{2}$, Wael Soliman ${ }^{1}$ and Yousreya Maklad ${ }^{3}$}

Dept. of Pharm. and Med. Chem. ( ${ }^{1}$ Pharm. Chem. Group, ${ }^{3}$ Pharmacol. Group) National Research Center, Dokki, Cairo, Egypt; ${ }^{2}$ Pharmaceutical Chemistry Dept., Faculty of Pharmacy, Cairo University, Cairo, Egypt.

\section{Abstract}

The synthesis of certain $N$-aralkyl(1-aminomethylcyclohexyl) benzenamines 6a-i, $\mathrm{N}$-(alkyloxymethyl or aralkyloxymethylcyclohexyl)$\mathrm{N}$-arylbenzenamines 9a-I and 1-(1-(aralkylphenylamino)cyclohexyl methoxy)-3-isopropylaminopropan-2-ols 11a-c has been accomplished. These compounds exhibited anticonvulsant activity. Compounds $9 \mathrm{~h}, \mathbf{9 b}$ and $11 \mathrm{a}$ at doses $0.06,0.075$ and $0.08 \mathrm{mmol} / \mathrm{kg}$, respectively provoked maximal anticonvulsant potential against pentylenetetrazol (PTZ) induced seizures test compared with diphenylhydantoin $(0.2 \mathrm{mmol} / \mathrm{kg})$ and valproic acid $(0.24 \mathrm{mmol} / \mathrm{kg})$.

\section{Key Words}

$\mathrm{N}$-aralkyl- $\mathrm{N}$-(1-substitutedcyclohexyl)benzenamines, 1-(1(aralkylphenyl amino)cyclohexylmethoxy)-3-isopropylaminopropan-2-ol, anticonvulsant activity.

\section{Introduction}

Many 1,1-disubstituted cyclohexane amines have been reported to display anticonvulsant potential, such as 1-(4-methoxyphenylamino)- $\mathrm{N}$ ((pyrrolidin-1-yl)methyl)cyclohexane carboxamide I [1]. 


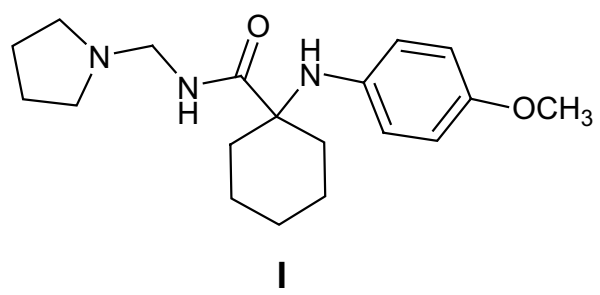

$N$-((1-(piperidin-1-yl)cyclohexyl)methyl)- $N$-(3,4,5-

trimethoxybenzyl)-benzamide, II (5 mg, $0.01 \mathrm{mmol} / \mathrm{kg})$ [2] has been reported to provoke maximal anticonvulsant activity in PTZ test compared with diphenylhydantoin (50 mg, 0.2mmol/kg).<smiles>COc1cc(CN(CC2(N3CCCCC3)CCCCC2)C(=O)c2ccccc2)cc(OC)c1OC</smiles>

II

These results instigated the synthesis of three series of 1-substituted cyclohexyl benzenamines namely $\mathrm{N}$-aralkyl(1-amino methylcyclohexyl)benzenamines 6a-i (Scheme I, Table 3), $\quad N$-(alkyl oxymethyl or aralkyloxymethylcyclohexyl)- $N$-arylbenzenamines 9a-I, in addition to 1-(1-(aralkylphenylamino)cyclohexylmethoxy)-3-isopropyl aminopropan-2-ols, 11a-c (Scheme II, Table 4,6) to screen their anticonvulsant activities.

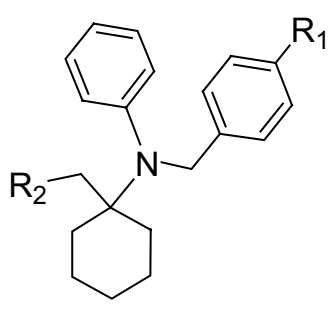

6a-i

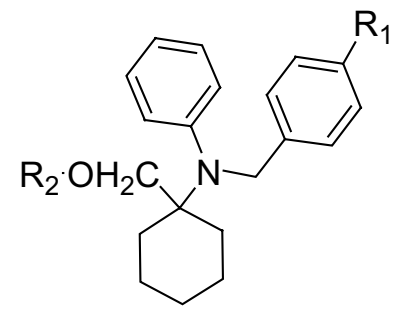

9a-I 


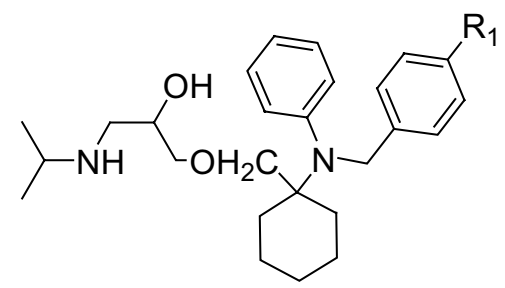

$11 \mathrm{a}$

\section{Results and Discussion}

\section{Chemistry}

Synthesis of $\mathrm{N}$-aralkyl(1-aminomethylcyclohexyl)benzenamines, 6a-i was illustrated in Scheme I, Table 3.

1-(Phenylamino)cyclohexanecarboxylic acid (3) was prepared from 1-(phenylamino)cyclohexanecarbonitrile (1) which was then hydrolyzed in two steps using conc. sulphuric acid then conc. hydrochloric acid [3].

1-( $\mathrm{N}$-arylanilido) cyclohexane carboxylic acids $4 \mathrm{a}-\mathrm{c}$ have been prepared as described [4].

The $N$-(amidocyclohexyl)- $N$-phenylbenzamides, 5a-i were obtained in high yields by adopting the mixed anhydride method using $4 \mathrm{a}-\mathrm{c}$ and trifluoroacetic anhydride followed by the addition of the appropriate amine. Subsequent hydride reduction of the two amidic carbonyl groups of $5 \mathrm{a}-\mathbf{i}$ gave the target compounds $\mathrm{N}$-aralkyl(1-aminomethyl) cyclohexanebenzamines 6a-i.

The synthesis of both $N$-(alkyloxymethyl or aralkyloxy methylcyclohexyl)- $N$-arylbenzenamines, $9 a-I$ and 1-(1-(aralkylphenyl amino)cyclohexylmethoxy)-3-isopropylaminopropan-2-ol, 11a-c were illustrated in Scheme II, Table 4,6.

Compound $\mathbf{8 b}$, which is not reported before, has been synthesized by following our reported procedure for the preparation of $\mathbf{8 a}$ and $\mathbf{8 c}$ [4] through esterification of $\mathbf{4 b}$ with methanol in the presence of catalytic amount of p-toulenesulphonic acid to afford the corresponding ester $\mathbf{7 b}$ 
and subsequent $\mathrm{LiAlH}_{4}$ reduction of both the ester and the tertiary amidic groups to afford the desired amino alcohols 8a-c in high yields.

Compounds 9a-I and 10a-c were obtained through the etherification of the amino alcohols 8a-c with the appropriate aralkyl, aminoalkyl halide (in case of 9a-I) and epichlorohydrin (in case of 10ac) in the presence of sodium hydride in DMF (c.f. Table 4,5).

Subsequent treatment of $10 \mathrm{a}-\mathrm{c}$ with isopropylamine adopting the procedure of Osa et al. [5] resulted in the corresponding 1-(1-(aralkyl phenylamino)cyclohexylmethoxy)-3-isopropylaminopropan-2-ols, 11a-c in high yields (c.f. Table 6).

\section{SCHEME I}
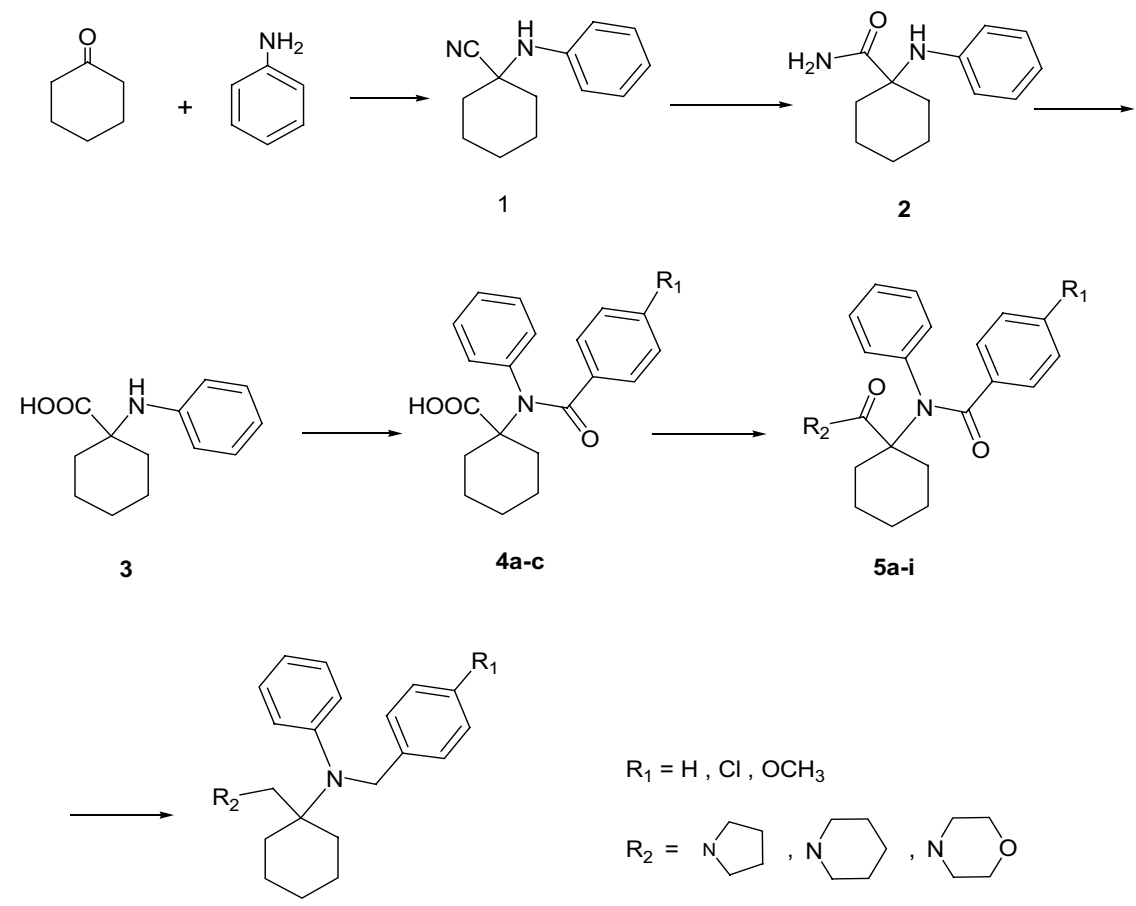


\section{SCHEME II}
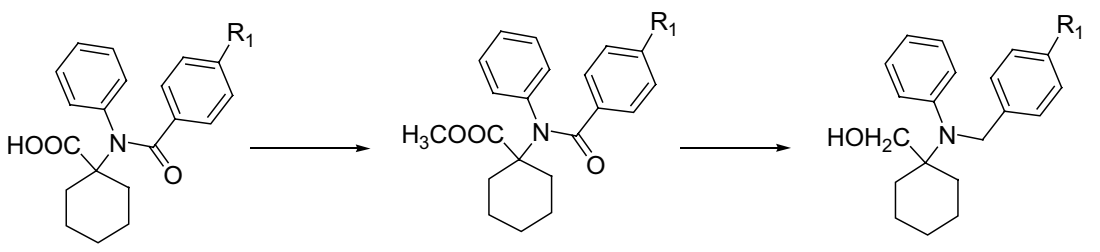

7a-c

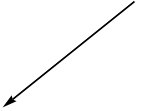

8a-c

4a-c

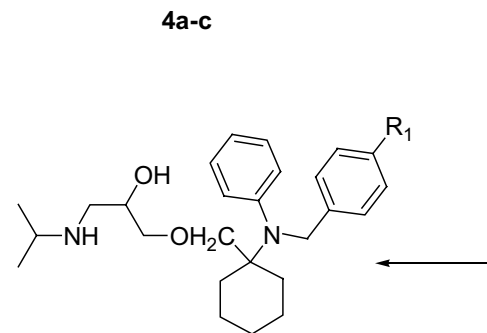

$11 a-c$

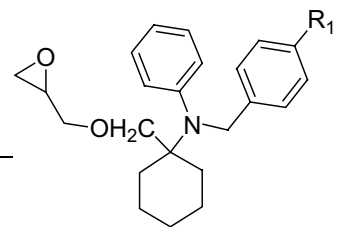

10a-c

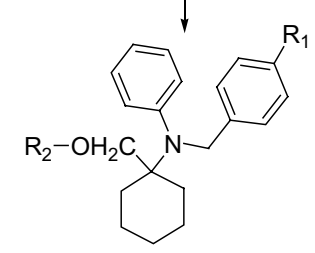

9a-I

$\mathrm{R}_{1}=\mathrm{H}, \mathrm{Cl}, \mathrm{OCH}_{3}$

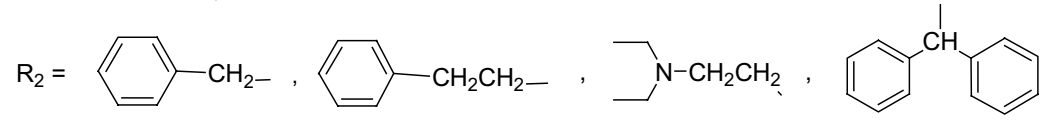

\section{Pharmacology}

The data presented in Table 1 illustrates the anticonvulsant potential of the $6 \mathrm{a}-\mathbf{i}, 9 \mathrm{a}-\mathrm{I}$ and $11 \mathrm{a}-\mathrm{c}$ series compared with diphenylhydantoin and valproic acid used as reference drugs.

In the 6a-i series the $N$-benzyl- $N-(1-(($ pyrrolidin-1-yl)methyl) cyclohexyl)benzenamine (6a), the $N$-benzyl- $N-(1-(($ piperidin-1yl)methyl)cyclohexyl)benzenamine (6b) and the $N$-(4-methoxybenzyl)$\mathrm{N}$-(1-((piperidin-1-yl)methyl)cyclohexyl)benzenamine (6h), exhibited $100 \%$ protection against pentylenetetrazol seizures at a dose level of $0.11 \mathrm{mmol} / \mathrm{kg}$, while diphenylhydantoin sodium and valproic acid, used as reference drugs, reached the same protection level at dose levels of 0.20 and $0.24 \mathrm{mmol} / \mathrm{kg}$, respectively. Moreover, the $\mathrm{N}$-benzyl- $\mathrm{N}-(1-$ (morpholinomethyl)cyclohexyl)benzenamine (6c) and the (4-chlorobenzyl)-N-(1-(morpholinomethyl)cyclohexyl)benzenamine (6f) exhibited 
an equipotent protection potential of $87.50 \%$ at the tested dose level $(0.11 \mathrm{mmol} / \mathrm{kg})$. Regarding the structure-activity relationship, the different congeners of the $6 a-i$ series showed a decrease in the anticonvulsant potential in the following order $6 a=6 b=6 h>6 c=6 f>$ $6 \mathrm{~d}=6 \mathrm{i}>6 \mathrm{e}=6 \mathrm{~g}$.

Concerning the 9a-I and 11a-c series (c.f. Table 1), compounds 9h (0.06 mmol/kg), 9b (0.075 mmol/kg), 11a $(0.08 \mathrm{mmol} / \mathrm{kg})$ and $9 \mathrm{k}$ $(0.11 \mathrm{mmol} / \mathrm{kg})$ displayed $100 \%$ protection compared with diphenylhydantoin $(0.2 \mathrm{mmol} / \mathrm{kg})$ and valproic acid $(0.24 \mathrm{mmol} / \mathrm{kg})$ used as reference drugs. Whereas, compounds $9 \mathrm{~d}, \mathbf{9 e}, \mathbf{9 g}, \mathbf{9 i}, \mathbf{9 j}, \mathbf{9 l}$ and $\mathbf{1 1 c}$ exhibited equipotent protection potential of $75 \%$ at a dose level 0.11 $\mathrm{mmol} / \mathrm{kg}$. Regarding the structure-activity relationship, the anticonvulsant activity was arranged in the following decreasing order: $9 h>9 b>11 a>9 k>9 d=9 e=9 g=9 i=9 j=9 l=11 c>9 c=9 f>11 b$.

Moreover, compounds $6 a, 6 b, 6 h, 9 b, 9 h 9 k$ and $11 a$ which displayed $100 \%$ protection were assayed in a dose up to 10 times the tested dose $(1.1 \mathrm{mmol} / \mathrm{kg})$ and did not prove to be toxic, since neither mortality nor toxic manifestations were observed up to 24 hours after compound administration. The $\mathrm{ED}_{50}$ for compound $9 \mathrm{~h}$ was 0.034 $\mathrm{mmol} / \mathrm{kg}$ with $95 \%$ confidence limits of 0.023 and $0.05 \mathrm{mmol} / \mathrm{kg}$.

In conclusion, the results of the present study revealed that the maximal potential in the 6a-li series was achieved with the compounds having the pyrrolidine $\mathbf{6 a}$ and the piperidine $\mathbf{6 b}$ and $\mathbf{6 h}$ heterocyclic moieties in their side chains at dose of $0.11 \mathrm{mmol} / \mathrm{kg}$. Meanwhile, regarding the $\mathbf{9 a}-\mathrm{I}$ and $11 \mathrm{a}-\mathrm{c}$ series, compound $\mathbf{9 h}(0.06 \mathrm{mmol} / \mathrm{kg}), \mathbf{9 b}$ $(0.075 \mathrm{mmol} / \mathrm{kg})$, and $11 \mathrm{c}(0.08 \mathrm{mmol} / \mathrm{kg})$ exhibited the $100 \%$ protection at dose level lower than that exerted by the $6 \mathrm{a}-\mathrm{i}$ series. 
Table 1: Anticonvulsant activity of compounds 6a-i, 9a-l and $11 a-c$ against lethal effect of pentylenetertazol induced seizers in adult male albino mice arranged in decreasing order according to the percentage of protection.

\begin{tabular}{|c|c|c|c|c|c|c|c|}
\hline Comp. & $\begin{array}{c}\text { Dose } \\
\mathrm{mmol} / \mathrm{kg}\end{array}$ & $\begin{array}{c}\text { No. of } \\
\text { Survival }\end{array}$ & $\begin{array}{c}\% \\
\text { protection }\end{array}$ & Comp. & $\begin{array}{c}\text { Dose } \\
\mathrm{mmol} / \mathrm{kg}\end{array}$ & $\begin{array}{c}\text { No. of } \\
\text { Survival }^{*}\end{array}$ & $\begin{array}{c}\% \\
\text { protection }\end{array}$ \\
\hline Control & - & 0 & 0 & $9 a$ & 0.11 & 7 & 87.50 \\
\hline \multirow{3}{*}{$\begin{array}{l}\text { Diphenyl } \\
\text { hydantoin }\end{array}$} & 0.06 & 4 & 50.00 & 9d & 0.11 & 6 & 75.00 \\
\hline & 0.10 & 5 & 62.50 & $9 e$ & 0.11 & 6 & 75.00 \\
\hline & 0.20 & 8 & 100 & $9 g$ & 0.11 & 6 & 75.00 \\
\hline \multirow{2}{*}{$\begin{array}{l}\text { Valproic } \\
\text { acid }\end{array}$} & 0.17 & 6 & 75.00 & $9 i$ & 0.11 & 6 & 75.00 \\
\hline & 0.24 & 8 & 100 & 9j & 0.11 & 6 & 75.00 \\
\hline $9 h$ & 0.06 & 8 & 100 & 91 & 0.11 & 6 & 75.00 \\
\hline $9 b$ & 0.75 & 8 & 100 & $11 \mathrm{c}$ & 0.11 & 6 & 75.00 \\
\hline $11 a$ & 0.08 & 8 & 100 & $9 c$ & 0.11 & 5 & 62.50 \\
\hline $6 a$ & 0.11 & 8 & 100 & $9 f$ & 0.11 & 5 & 62.50 \\
\hline $6 b$ & 0.11 & 8 & 100 & $6 d$ & 0.11 & 4 & 50.00 \\
\hline $6 \mathrm{~h}$ & 0.11 & 8 & 100 & $6 i$ & 0.11 & 4 & 50.00 \\
\hline $9 k$ & 0.11 & 8 & 100 & $6 e$ & 0.11 & 3 & 37.50 \\
\hline $6 c$ & 0.11 & 7 & 87.50 & $6 \mathrm{~g}$ & 0.11 & 3 & 37.50 \\
\hline $6 f$ & 0.11 & 7 & 87.50 & $11 b$ & 0.11 & 1 & 12.50 \\
\hline
\end{tabular}

* out of eight animals

\section{Experimental}

\section{Chemistry}

All melting points were uncorrected and determined with Electrothermal Capillary melting point apparatus. 
Infrared (IR) spectra were recorded as thin film (for oils) in $\mathrm{KBr}$ discs or in $\mathrm{KBr}$ pellets (for solids) with Philips PU $9712 \mathrm{IR}$ and Schimadzu IR 435 spectrometer and values are reported in $\mathrm{cm}^{-1}$.

${ }^{1} \mathrm{H}$ NMR and ${ }^{13} \mathrm{C}$ NMR spectra were carried out on Varian Mercury VX $300 \mathrm{MHz}$ Spectrophotometer using TMS as an internal standard. Chemical shift values are recorded in ppm $\delta$ scale.

Mass spectral data were recorded as chemical ionization $\left(\mathrm{Cl} / \mathrm{CH}_{4}\right)$ from a Finnigan Mat SSQ-7000 Spectrophotometer.

Elemental analyses were carried out in Microanalytical Unit, National Research Centre.

General procedure for the preparation of $\mathrm{N}$-(amidocyclohexyl)-Nphenylbenzamides, 5a-i

To a stirred solution of $0.01 \mathrm{~mol}$ of the acids $4 \mathrm{a}-\mathrm{c}$ [4] in $20 \mathrm{~mL}$ of dry THF, $0.01 \mathrm{~mol}(2.1 \mathrm{~g}, 1.4 \mathrm{~mL})$ of trifluoroacetic anhydride was added dropwise at $5^{\circ} \mathrm{C}$ and stirred for $5 \mathrm{~min}$. at $5^{\circ} \mathrm{C}$. The appropriate amine (0.01 mol) was added in one portion. The mixture was left over night under continuous stirring, evaporated under vacuum and the resulted oils were dissolved in methylene chloride, washed with sodium carbonate, dilute $\mathrm{HCl}$ and finally with distilled water (20 $\mathrm{mL}$ each). The organic layer was dried over anhydrous $\mathrm{MgSO}_{4}$ and evaporated under vacuum, the residual solids were crystallized from isopropanol to give the corresponding amides 5a-i (c.f. Table 2).

Table 2: Physical and analytical data of $N$-(amidocyclohexyl)- $N-$ phenylarylamides, 5a-i

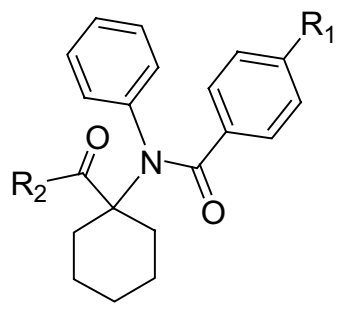




\begin{tabular}{|c|c|c|c|c|c|c|c|c|c|c|}
\hline \multirow[b]{2}{*}{ No. } & \multirow[b]{2}{*}{$\mathbf{R}_{1}$} & \multirow[b]{2}{*}{$\mathbf{R}_{2}$} & \multirow[b]{2}{*}{$\begin{array}{c}\text { Yield } \\
(\%)\end{array}$} & \multirow[b]{2}{*}{$\underset{{ }^{\circ} \mathrm{C} . p .}{ }$} & \multirow[b]{2}{*}{$\begin{array}{l}\text { Formula } \\
\text { Mol.Wt. }\end{array}$} & \multirow{2}{*}{$\begin{array}{c}\mathrm{Cl} / \mathrm{CH}_{4}, \\
\mathrm{~m} / \mathbf{z} \\
(\mathrm{M}+\mathrm{H})^{+}\end{array}$} & \multicolumn{4}{|c|}{ Microanalysis \% } \\
\hline & & & & & & & & C & $\mathbf{H}$ & $\mathbf{N}$ \\
\hline $5 a$ & $\mathrm{H}$ & & 85 & $188-9$ & $\begin{array}{c}\mathrm{C}_{24} \mathrm{H}_{28} \mathrm{~N}_{2} \mathrm{O}_{2} \\
376.49\end{array}$ & 377.5 & $\begin{array}{l}\text { Calc. } \\
\text { F. }\end{array}$ & $\begin{array}{l}76.56 \\
76.75\end{array}$ & $\begin{array}{l}7.50 \\
7.39\end{array}$ & $\begin{array}{l}7.44 \\
7.54\end{array}$ \\
\hline $5 b$ & $\mathrm{H}$ & $N$ & 95 & $182-3$ & $\begin{array}{c}\mathrm{C}_{25} \mathrm{H}_{30} \mathrm{~N}_{2} \mathrm{O}_{2} \\
390.52\end{array}$ & 391.5 & $\begin{array}{c}\text { Calc. } \\
\text { F. }\end{array}$ & $\begin{array}{l}76.89 \\
76.53\end{array}$ & $\begin{array}{l}7.74 \\
7.81\end{array}$ & $\begin{array}{l}7.17 \\
7.26\end{array}$ \\
\hline $5 c$ & $\mathrm{H}$ & & 92 & $174-5$ & $\begin{array}{c}\mathrm{C}_{24} \mathrm{H}_{28} \mathrm{~N}_{2} \mathrm{O}_{3} \\
392.49\end{array}$ & 393.5 & $\begin{array}{l}\text { Calc. } \\
\mathrm{F} .\end{array}$ & $\begin{array}{l}73.44 \\
73.16\end{array}$ & $\begin{array}{l}7.19 \\
7.05\end{array}$ & $\begin{array}{l}7.14 \\
7.23\end{array}$ \\
\hline $5 d$ & $\mathrm{Cl}$ & & 95 & $170-1$ & $\begin{array}{c}\mathrm{C}_{24} \mathrm{H}_{27} \mathrm{CIN}_{2} \mathrm{O}_{2} \\
410.94\end{array}$ & 412 & $\begin{array}{l}\text { Calc. } \\
\mathrm{F} .\end{array}$ & $\begin{array}{l}70.15 \\
69.85\end{array}$ & $\begin{array}{l}6.62 \\
6.49\end{array}$ & $\begin{array}{l}6.68 \\
6.55\end{array}$ \\
\hline $5 e$ & $\mathrm{Cl}$ & $N$ & 91 & $168-9$ & $\begin{array}{c}\mathrm{C}_{25} \mathrm{H}_{29} \mathrm{ClN}_{2} \mathrm{O}_{2} \\
424.96\end{array}$ & 425.9 & $\begin{array}{c}\text { Calc. } \\
\text { F. }\end{array}$ & $\begin{array}{l}70.66 \\
70.82 \\
\end{array}$ & $\begin{array}{l}6.88 \\
6.63\end{array}$ & $\begin{array}{l}6.59 \\
6.62 \\
\end{array}$ \\
\hline $5 f$ & $\mathrm{Cl}$ & $N$ & 90 & 186-7 & $\begin{array}{c}\mathrm{C}_{24} \mathrm{H}_{27} \mathrm{CIN}_{2} \mathrm{O}_{3} \\
426.94\end{array}$ & 427.9 & $\begin{array}{c}\text { Calc. } \\
\text { F. }\end{array}$ & $\begin{array}{l}67.52 \\
67.27 \\
\end{array}$ & $\begin{array}{l}6.37 \\
6.22 \\
\end{array}$ & $\begin{array}{l}6.56 \\
6.44 \\
\end{array}$ \\
\hline $5 g$ & $\mathrm{OCH}_{3}$ & & 83 & $198-9$ & $\begin{array}{c}\mathrm{C}_{24} \mathrm{H}_{29} \mathrm{~N}_{2} \mathrm{O}_{3} \\
393.50\end{array}$ & 394.5 & $\begin{array}{c}\text { Calc. } \\
\text { F. }\end{array}$ & $\begin{array}{l}73.25 \\
73.05\end{array}$ & $\begin{array}{l}7.43 \\
7.53\end{array}$ & $\begin{array}{l}7.12 \\
6.95\end{array}$ \\
\hline $5 \mathrm{~h}$ & $\mathrm{OCH}_{3}$ & $\Lambda$ & 94 & $169-70$ & $\begin{array}{c}\mathrm{C}_{26} \mathrm{H}_{32} \mathrm{~N}_{2} \mathrm{O}_{3} \\
420.54\end{array}$ & 421.5 & $\begin{array}{l}\text { Calc. } \\
\text { F. }\end{array}$ & $\begin{array}{l}74.26 \\
73.99 \\
\end{array}$ & $\begin{array}{l}7.67 \\
7.41 \\
\end{array}$ & $\begin{array}{l}6.66 \\
6.49 \\
\end{array}$ \\
\hline $5 i$ & $\mathrm{OCH}_{3}$ & & 93 & $195-6$ & $\begin{array}{c}\mathrm{C}_{25} \mathrm{H}_{30} \mathrm{~N}_{2} \mathrm{O}_{4} \\
422.52\end{array}$ & 423.5 & $\begin{array}{c}\text { Calc. } \\
\text { F. }\end{array}$ & $\begin{array}{l}71.07 \\
70.77\end{array}$ & $\begin{array}{l}7.16 \\
6.97\end{array}$ & $\begin{array}{l}6.63 \\
6.68\end{array}$ \\
\hline
\end{tabular}

IR revealed the presence of anilido $\mathrm{C}=\mathrm{O}$ band 1680 and the other amidic $\mathrm{C}=\mathrm{O}$ at 1648 .

General procedure for the preparation of $\mathrm{N}$-aralkyl(1-aminomethylcyclohexyl)benzenamines, 6a-i

A solution of $0.02 \mathrm{~mol}$ of the amides $5 \mathrm{a}-\mathrm{i}$ in dry THF was added dropwise to a cold $\left(5-10^{\circ} \mathrm{C}\right)$ slurry of $0.04 \mathrm{~mol}(1.52 \mathrm{~g})$ of $\mathrm{LiAlH}_{4}$ in THF. The reaction mixture was stirred and refluxed for $24 \mathrm{~h}$. After cooling, the excess $\mathrm{LiAlH}_{4}$ was decomposed by slow addition of a saturated solution of $\mathrm{Na}_{2} \mathrm{SO}_{4}$. The precipitate was filtered off and washed with THF. The filtrate and washings were evaporated under vacuum to give viscous oils which were then purified through column chromatography using neutral alumina as a stationary phase and $n$-hexane : ethylacetate (8: 2) as a mobile phase to give oils of the corresponding amines 6a-i (c.f. Table 3). 
Table 3: Analytical data of $\mathrm{N}$-aralkyl(1-aminomethylcyclohexyl) Benzenamines, 6a-i

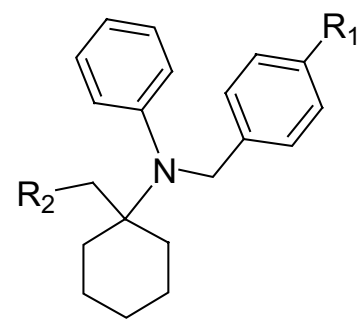

$6 a-i$

\begin{tabular}{|c|c|c|c|c|c|c|c|c|c|}
\hline \multirow[b]{2}{*}{ No. } & \multirow[b]{2}{*}{$\mathbf{R}_{1}$} & \multirow[b]{2}{*}{$\mathbf{R}_{\mathbf{2}}$} & \multirow{2}{*}{$\begin{array}{c}\text { Yield } \\
(\%)\end{array}$} & \multirow{2}{*}{$\begin{array}{l}\text { Formula } \\
\text { Mol.Wt. }\end{array}$} & \multirow{2}{*}{$\begin{array}{c}\mathrm{Cl} / \mathrm{CH}_{4}, \\
\mathrm{~m} / \mathbf{z} \\
(\mathrm{M}+\mathrm{H})^{+}\end{array}$} & \multicolumn{4}{|c|}{ Microanalysis \% } \\
\hline & & & & & & & C & H & $\mathbf{N}$ \\
\hline $6 a$ & $\mathrm{H}$ & & 95 & $\begin{array}{c}\mathrm{C}_{24} \mathrm{H}_{32} \mathrm{~N}_{2} \\
348.52\end{array}$ & 349.5 & $\begin{array}{c}\text { Calc. } \\
\text { F. }\end{array}$ & $\begin{array}{l}82.71 \\
82.39\end{array}$ & $\begin{array}{l}9.25 \\
9.31\end{array}$ & $\begin{array}{l}8.04 \\
7.88\end{array}$ \\
\hline $6 b$ & $\mathrm{H}$ & $\mathrm{N}$ & 90 & $\begin{array}{c}\mathrm{C}_{25} \mathrm{H}_{34} \mathrm{~N}_{2} \\
362.55\end{array}$ & 363.5 & $\begin{array}{l}\text { Calc. } \\
\text { F. }\end{array}$ & $\begin{array}{l}82.82 \\
82.55\end{array}$ & $\begin{array}{l}9.45 \\
9.49\end{array}$ & $\begin{array}{l}7.73 \\
7.65\end{array}$ \\
\hline $6 c$ & $\mathrm{H}$ & & 82 & $\begin{array}{c}\mathrm{C}_{24} \mathrm{H}_{32} \mathrm{~N}_{2} \mathrm{O} \\
364.52 \\
\end{array}$ & 365.5 & $\begin{array}{c}\text { Calc. } \\
\text { F. }\end{array}$ & $\begin{array}{l}79.08 \\
79.14 \\
\end{array}$ & $\begin{array}{l}8.85 \\
8.61 \\
\end{array}$ & $\begin{array}{l}7.68 \\
7.52 \\
\end{array}$ \\
\hline $6 d$ & $\mathrm{Cl}$ & & 83 & $\begin{array}{c}\mathrm{C}_{24} \mathrm{H}_{31} \mathrm{ClN}_{2} \\
382.97\end{array}$ & $\begin{array}{c}383 \\
\mathrm{M}^{+}\end{array}$ & $\begin{array}{c}\text { Calc. } \\
\text { F. }\end{array}$ & $\begin{array}{l}75.27 \\
74.91\end{array}$ & $\begin{array}{l}8.16 \\
7.99\end{array}$ & $\begin{array}{l}7.31 \\
7.35\end{array}$ \\
\hline $6 e$ & $\mathrm{Cl}$ & $\mathrm{N}$ & 92 & $\begin{array}{c}\mathrm{C}_{25} \mathrm{H}_{33} \mathrm{ClN}_{2} \\
397.00\end{array}$ & 398 & $\begin{array}{c}\text { Calc. } \\
\text { F. }\end{array}$ & $\begin{array}{l}75.63 \\
75.88 \\
\end{array}$ & $\begin{array}{l}8.38 \\
8.21 \\
\end{array}$ & $\begin{array}{l}7.06 \\
6.82 \\
\end{array}$ \\
\hline $6 f$ & $\mathrm{Cl}$ & & 85 & $\begin{array}{c}\mathrm{C}_{24} \mathrm{H}_{31} \mathrm{CIN}_{2} \mathrm{O} \\
398.97\end{array}$ & 400 & $\begin{array}{l}\text { Calc. } \\
\text { F. }\end{array}$ & $\begin{array}{l}72.25 \\
71.96 \\
\end{array}$ & $\begin{array}{l}7.83 \\
7.61 \\
\end{array}$ & $\begin{array}{l}7.02 \\
6.87 \\
\end{array}$ \\
\hline $6 g$ & $\mathrm{OCH}_{3}$ & & 81 & $\begin{array}{c}\mathrm{C}_{25} \mathrm{H}_{34} \mathrm{~N}_{2} \mathrm{O} \\
378.55\end{array}$ & 379.5 & $\begin{array}{l}\text { Calc. } \\
\text { F. }\end{array}$ & $\begin{array}{l}79.32 \\
79.04\end{array}$ & $\begin{array}{l}9.05 \\
8.86\end{array}$ & $\begin{array}{l}7.40 \\
7.49\end{array}$ \\
\hline $6 h$ & $\mathrm{OCH}_{3}$ & $N^{\prime}$ & 88 & $\begin{array}{c}\mathrm{C}_{26} \mathrm{H}_{36} \mathrm{~N}_{2} \mathrm{O} \\
392.58\end{array}$ & 393.6 & $\begin{array}{c}\text { Calc. } \\
\text { F. }\end{array}$ & $\begin{array}{l}79.55 \\
79.71\end{array}$ & $\begin{array}{l}9.24 \\
9.01\end{array}$ & $\begin{array}{l}7.14 \\
6.94\end{array}$ \\
\hline $6 i$ & $\mathrm{OCH}_{3}$ & & 90 & $\begin{array}{c}\mathrm{C}_{24} \mathrm{H}_{34} \mathrm{~N}_{2} \mathrm{O}_{2} \\
394.55\end{array}$ & 395.5 & $\begin{array}{c}\text { Calc. } \\
\text { F. }\end{array}$ & $\begin{array}{l}76.10 \\
75.75\end{array}$ & $\begin{array}{l}8.69 \\
8.78\end{array}$ & $\begin{array}{l}7.10 \\
6.98\end{array}$ \\
\hline
\end{tabular}

Methyl 1-(4-chloro-N-phenylbenzamido)cyclohexanecarboxylate (7b)

A solution of $0.01 \mathrm{~mol}$ of the acid $4 \mathrm{~b}, 0.04 \mathrm{~mol}(1.28 \mathrm{gm}, 1.62 \mathrm{~mL})$ of dry methanol and $0.002 \mathrm{~g}$ of p-toluenesulphonic acid in $30 \mathrm{~mL}$ of dry benzene was refluxed under stirring for $12 \mathrm{~h}$. The solvent was evaporated under vacuum and the residue was dissolved in chloroform. The chloroformic solution was washed with aqueous $\mathrm{Na}_{2} \mathrm{CO}_{3}$ solution then with water (20 mL each). The organic phase was dried over anhydrous $\mathrm{MgSO}_{4}$. The chloroform was driven off under vacuum and 
the residual solid was crystallized from ether-cyclohexane m.p. $=105-$ $106{ }^{\circ} \mathrm{C}$, analysis calculated for $\mathrm{C}_{21} \mathrm{H}_{22} \mathrm{CINO}_{3}$ : C: $67.83, \mathrm{H}: 5.96, \mathrm{~N}: 3.77$; Found: C: $67.98, \mathrm{H}: 5.89, \mathrm{~N}: 3.85$. IR revealed the presence of an ester band at 1735 and amide band at 1687 and El/MS, m/z (\%): $371, \mathrm{M}^{+}$, $\mathrm{C}_{21} \mathrm{H}_{22} \mathrm{CINO}_{3}{ }^{+}$(40); 298 (100).

\section{(1-((4-Chlorobenzyl)phenylamino)cyclohexyl)methanol (8b)}

A solution of $0.1 \mathrm{~mol}$ of the esters $7 \mathbf{b}$ in dry THF was added to a slurry of $0.15 \mathrm{~mol}(5.7 \mathrm{~g})$ of $\mathrm{LiAlH}_{4}$ in dry THF at $0^{\circ} \mathrm{C}$. The temperature of the reaction was raised gradually to room temperature and left for $5 \mathrm{~h}$, then refluxed for further $3 \mathrm{~h}$. The complex was decomposed using a saturated solution of $\mathrm{Na}_{2} \mathrm{SO}_{4}$ and filtered over celite. The filtrate was dried over anhydrous $\mathrm{Na}_{2} \mathrm{SO}_{4}$ and evaporated under vacuum to give the alcohol $\mathbf{8 b}$ as viscous oil.

IR showed $\mathrm{OH}$ band at $3450 . \mathrm{Cl} / \mathrm{CH}_{4}, \mathrm{~m} / \mathrm{z} \mathbf{8 b}: 326.4,(\mathrm{M}+\mathrm{H})^{+}$, Analysis calculated for $\mathrm{C}_{20} \mathrm{H}_{24} \mathrm{CINO}$ : C: $72,82, \mathrm{H}: 7.33, \mathrm{~N}: 4.25$; Found: C: 75.53 , $\mathrm{H}: 4.18$

\section{General procedure for the preparation of N-(alkyloxy or aralkyloxy methylcyclohexyl)-N-arylbenzenamines, 9a-I}

To a stirred mixture of $5 \mathrm{mmol}$ of the alcohols $8 \mathrm{a}-\mathrm{c}$, and $8 \mathrm{mmol}$ $(0.19 \mathrm{~g})$ of sodium hydride in DMF $(15 \mathrm{~mL})$ was added dropwise $6 \mathrm{mmol}$ of the appropriate aralkyl halide or 2-diethylaminoethyl chloride $\mathrm{HCl}$ in DMF $(5 \mathrm{~mL})$. The reaction mixture was stirred at room temperature for $30 \mathrm{~min}$., then heated at $80^{\circ} \mathrm{C}$ for $4 \mathrm{~h}$. The mixture was cooled to room temperature, diluted with water $(10 \mathrm{~mL})$ and extracted with ethyl acetate (15 $\mathrm{mL} \times 3$ ). For compounds $\mathbf{9 a}, \mathbf{b}, \mathbf{d}, \mathbf{e}, \mathbf{f}, \mathbf{h}, \mathbf{I}, \mathbf{j}$ and I the organic extracts were dried over $\mathrm{MgSO}_{4}$, filtered and evaporated under vacuum to give viscous oils of the corresponding ethers, which were then purified through column chromatography using neutral alumina as a stationary phase and $\mathrm{n}$-hexane : ethyl acetate $(9.5: 0.5)$ as a mobile phase to give pale yellow oils of the corresponding ethers $\mathbf{9 a}, \mathbf{b}, \mathbf{e}, \mathbf{f}, \mathbf{i}$ and $\mathbf{j}$ and 
white solids for compounds $\mathbf{9 d}, \mathbf{h}$ and I. For compounds $\mathbf{9 c , g}$ and $\mathbf{k}$ the ethyl acetate was driven off and the residual oil was acidified with $10 \mathrm{~mL}$ of $2 \mathrm{~N} \mathrm{HCl}$, then washed with ether $(3 \times 15 \mathrm{~mL})$. The acidic layer was separated and rendered alkaline with $10 \%$ sodium hydroxide solution and extracted with ethyl acetate $(3 \times 25 \mathrm{~mL})$. The organic layer was separated and dried over anhydrous $\mathrm{MgSO}_{4}$ and evaporated under vacuum to give viscous oils of the target compounds (c.f. Table 4).

\section{General procedure for the preparation of N-(1-(((oxiran-2-yl) methoxy) methyl)cyclohexyl)-N-aralkylbezeneamine, 10a-c :}

To a stirred mixture of $5 \mathrm{mmol}$ of the alcohols $8 \mathbf{a}-\mathbf{c}$, and $8 \mathrm{mmol}$ $(0.19 \mathrm{~g})$ of sodium hydride in DMF $(15 \mathrm{~mL})$ was added dropwise $6 \mathrm{mmol}$ of epichlorohydrin $(0.55 \mathrm{~g}, 0.47 \mathrm{~mL})$ in DMF $(5 \mathrm{~mL})$. The reaction mixture was stirred at room temperature for $30 \mathrm{~min}$., then heated at $80^{\circ} \mathrm{C}$ for $4 \mathrm{~h}$. The mixture was cooled to room temperature, diluted with water $(10 \mathrm{~mL})$ and extracted with ethyl acetate $(15 \mathrm{~mL} \times 3)$. The organic extracts were dried over $\mathrm{MgSO}_{4}$, filtered and evaporated under vacuum to give viscous oils of the corresponding ether which were then purified through column chromatography using neutral alumina as a stationary phase and $n$-hexane : ethyl acetate $(9.5: 0.5)$ as a mobile phase to give pale yellow oils of the corresponding ethers 10a-c (c.f. Table 5).

Table 4: $N$-(alkyloxy or aralkyloxy methylcyclohexyl)- $N$-aryl benzen amines, 9a-I

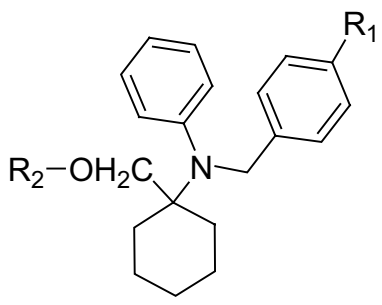




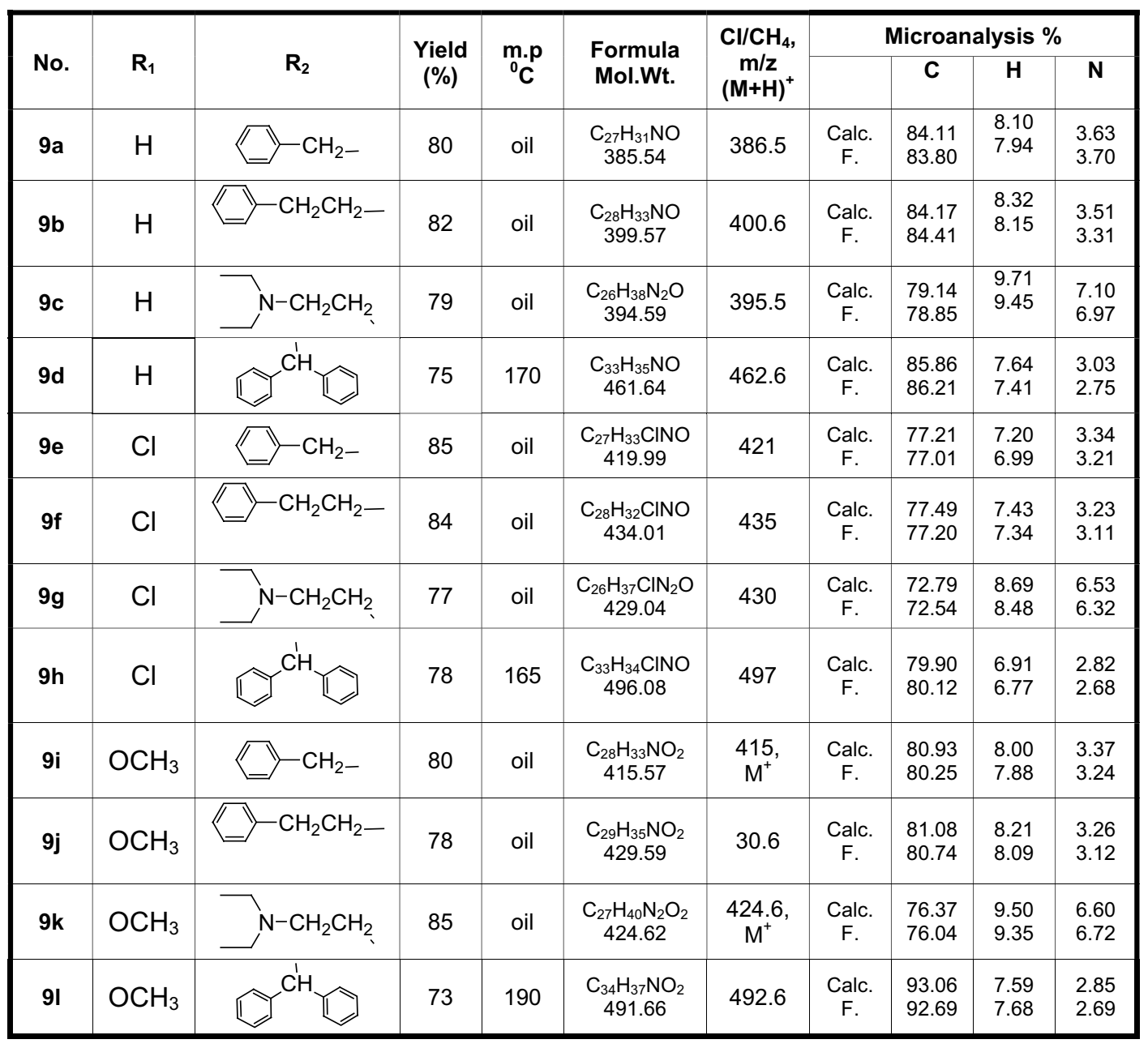

Table 5: Analytical data of $N-(1-(($ oxiran-2-yl) methoxy) methyl) cyclohexyl)- $N$-aralkylbezeneamine, 10a-c

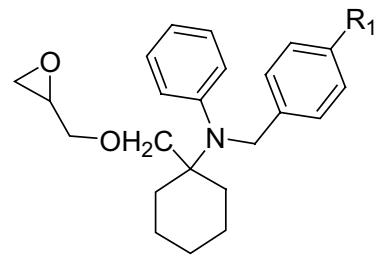

$10 \mathrm{a}-\mathrm{c}$ 


\begin{tabular}{|c|c|c|c|c|c|c|c|c|}
\hline \multirow[b]{2}{*}{ No. } & \multirow[b]{2}{*}{$\mathbf{R}_{1}$} & \multirow{2}{*}{$\begin{array}{c}\text { Yield } \\
(\%)\end{array}$} & \multirow{2}{*}{$\begin{array}{l}\text { Formula } \\
\text { Mol.Wt. }\end{array}$} & \multirow[b]{2}{*}{$\begin{array}{c}\mathrm{Cl} / \mathrm{CH}, \mathrm{m} / \mathrm{z} \\
(\mathrm{M}+\mathrm{H})^{+}\end{array}$} & \multicolumn{4}{|c|}{ Microanalysis \% } \\
\hline & & & & & & C & $\mathbf{H}$ & $\mathbf{N}$ \\
\hline $10 a$ & $\mathrm{H}$ & 75 & $\begin{array}{c}\mathrm{C}_{23} \mathrm{H}_{29} \mathrm{NO}_{2} \\
351.48\end{array}$ & 352.48 & $\begin{array}{c}\text { Calc. } \\
\text { F. }\end{array}$ & $\begin{array}{l}78.59 \\
78.22 \\
\end{array}$ & $\begin{array}{l}8.32 \\
8.18 \\
\end{array}$ & $\begin{array}{l}3.99 \\
2.84\end{array}$ \\
\hline $10 \mathrm{~b}$ & $\mathrm{Cl}$ & 80 & $\begin{array}{c}\mathrm{C}_{23} \mathrm{H}_{28} \mathrm{ClNO}_{2} \\
385.93\end{array}$ & 387 & $\begin{array}{c}\text { Calc. } \\
\text { F. }\end{array}$ & $\begin{array}{l}71.58 \\
71.84 \\
\end{array}$ & $\begin{array}{l}7.31 \\
7.21 \\
\end{array}$ & $\begin{array}{l}3.63 \\
3.52 \\
\end{array}$ \\
\hline $10 c$ & $\mathrm{OCH}_{3}$ & 78 & $\begin{array}{c}\mathrm{C}_{24} \mathrm{H}_{31} \mathrm{NO}_{3} \\
381.51\end{array}$ & $381.5, \mathrm{M}^{+}$ & $\begin{array}{c}\text { Calc. } \\
\mathrm{F} .\end{array}$ & $\begin{array}{l}75.56 \\
75.24\end{array}$ & $\begin{array}{l}8.19 \\
8.27\end{array}$ & $\begin{array}{l}3.67 \\
3.58\end{array}$ \\
\hline
\end{tabular}

\section{General procedure for the preparation of 1-(1-(aralkylphenyl} amino) cyclohexylmethoxy)-3- isopropylaminopropan-2-ols, 11a-c

A mixture of $0.01 \mathrm{~mol}$ of the epoxy compounds $10 \mathrm{a}-\mathrm{c}$ and $0.05 \mathrm{~mol}$ $(3 \mathrm{~g}, 4.3 \mathrm{~mL})$ of isopropylamine was stirred at room temperature in the presence of $0.01 \mathrm{~mol}(1 \mathrm{~g}, 0.9 \mathrm{~mL})$ of triethylamine for $24 \mathrm{~h}$ in isopropylamine $(25 \mathrm{~mL})$. The reaction mixture was evaporated to dryness and the residue was acidified with $10 \mathrm{~mL}$ of $2 \mathrm{~N} \mathrm{HCl}$, and then extracted with ether $(3 \times 10 \mathrm{~mL})$. The acidic layer was separated and rendered alkaline with $10 \%$ sodium hydroxide solution, extracted with ethyl acetate $(3 \times 25 \mathrm{~mL})$, dried over anhydrous $\mathrm{MgSO}_{4}$ and evaporated under vacuum to give viscous oils which was then purified through column chromatography using neutral alumina as a stationary phase and $n$-hexane : ethyl acetate $(9: 1)$ as a mobile phase to give clear colourless oils of the corresponding alcohols 11a-c which were converted to the corresponding monohydrochloride salts by treating with methanolic- $\mathrm{HCl}$ solution (c.f. Table 6).

IR showed of $\mathrm{NH}$ band at 3330 and alcoholic $\mathrm{OH}$ bands at 3550

Table 6: Physical data of of 1-(1-(aralkylphenyl amino)cyclohexylmethoxy)-3-isopropylaminopropan-2-ols, 11a-c

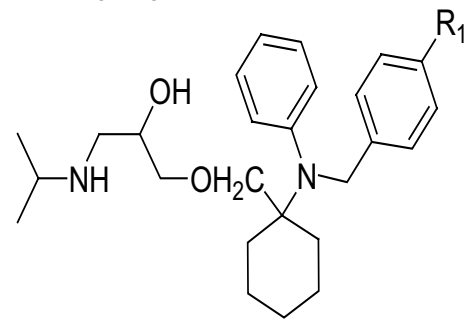

11a-c 


\begin{tabular}{|c|c|c|c|c|c|c|c|c|c|}
\hline \multirow[b]{2}{*}{ No. } & \multirow[b]{2}{*}{$\mathbf{R}_{1}$} & \multirow{2}{*}{$\begin{array}{c}\text { Yield } \\
(\%)\end{array}$} & \multirow{2}{*}{$\underset{{ }^{0} \mathrm{C}}{\mathrm{m} . \mathrm{p}}$} & \multirow{2}{*}{$\begin{array}{l}\text { Formula } \\
\text { Mol.Wt. }\end{array}$} & \multirow[b]{2}{*}{$\begin{array}{c}\mathrm{Cl} / \mathrm{CH}_{4}, \\
\mathrm{~m} / \mathrm{z} \\
(\mathrm{M}+\mathrm{H})^{+}\end{array}$} & \multicolumn{4}{|c|}{ Microanalysis \% } \\
\hline & & & & & & & C & H & $\mathbf{N}$ \\
\hline $11 a$ & $\mathrm{H}$ & 82 & $\begin{array}{c}\text { Oil } \\
130-1^{*}\end{array}$ & $\begin{array}{c}\mathrm{C}_{26} \mathrm{H}_{38} \mathrm{~N}_{2} \mathrm{O}_{2} \\
410.59\end{array}$ & 411.6 & $\begin{array}{l}\text { Calc. } \\
\text { F. }\end{array}$ & $\begin{array}{l}76.06 \\
75.74\end{array}$ & $\begin{array}{l}9.33 \\
9.39\end{array}$ & $\begin{array}{l}6.82 \\
6.74\end{array}$ \\
\hline $11 b$ & $\mathrm{Cl}$ & 85 & $\begin{array}{c}\text { Oil } \\
142.3^{*}\end{array}$ & $\begin{array}{c}\mathrm{C}_{26} \mathrm{H}_{37} \mathrm{ClN}_{2} \mathrm{O}_{2} \\
445.04\end{array}$ & 446 & $\begin{array}{l}\text { Calc. } \\
\text { F. }\end{array}$ & $\begin{array}{l}70.17 \\
69.85\end{array}$ & $\begin{array}{l}8.38 \\
8.24\end{array}$ & $\begin{array}{l}9.29 \\
9.36\end{array}$ \\
\hline $11 \mathrm{c}$ & $\mathrm{OCH}_{3}$ & 80 & $\begin{array}{c}\text { Oil } \\
122-3^{*}\end{array}$ & $\begin{array}{c}\mathrm{C}_{27} \mathrm{H}_{40} \mathrm{~N}_{2} \mathrm{O}_{3} \\
440.62\end{array}$ & 441.5 & $\begin{array}{l}\text { Calc. } \\
\text { F. }\end{array}$ & $\begin{array}{l}73.60 \\
73.91\end{array}$ & $\begin{array}{l}9.15 \\
9.04\end{array}$ & $\begin{array}{l}6.36 \\
6.28\end{array}$ \\
\hline
\end{tabular}

* Melting point of the corresponding monohydrochloride salts

Table 7: ${ }^{1} \mathrm{H}$ NMR* Data of 5c, 5e, 5g, 6a, 6e, 6i, 9a, 9f, 9h, 9k, 10b and $11 \mathrm{a} \&^{13}$ CNMR $^{*}$ Data of $5 \mathrm{c}, 5 \mathrm{e}, 5 \mathrm{~g}, 6 \mathrm{a}, 6 \mathrm{e}, 6 \mathrm{i}, 9 \mathrm{f}, 9 \mathrm{~h}$, and $10 \mathrm{~b}$.

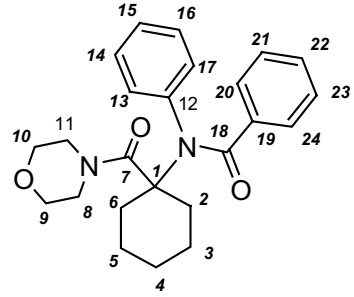

$5 c$

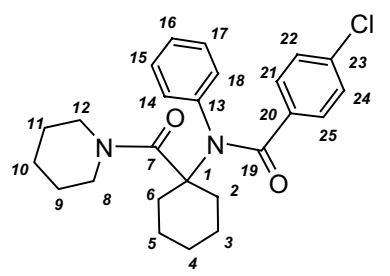

$5 e$

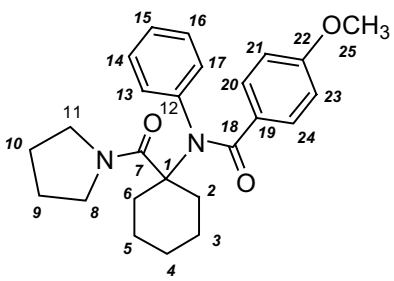

$5 \mathrm{~g}$

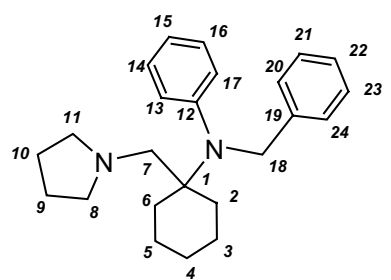

$6 a$

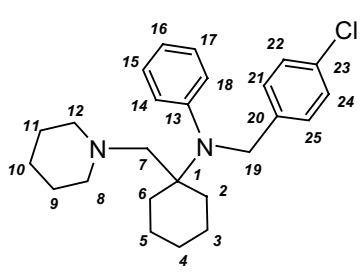

$6 e$

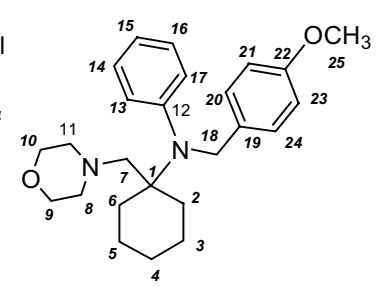

$6 \mathbf{i}$

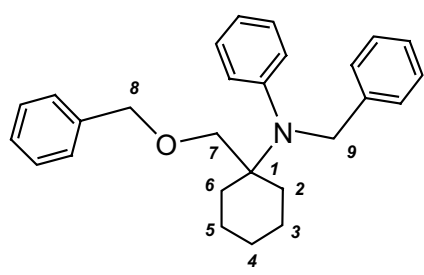

$9 a$

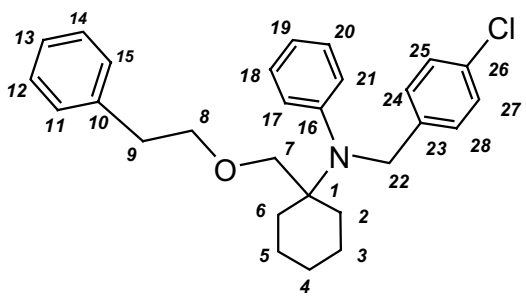

9f 


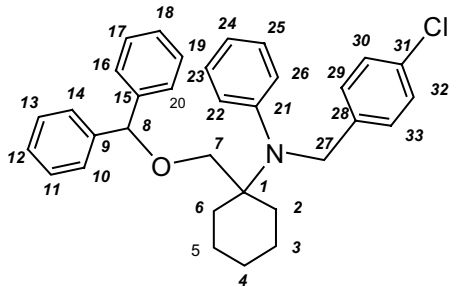

9h

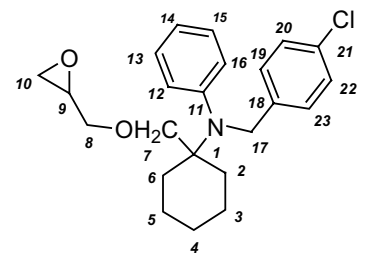

10b

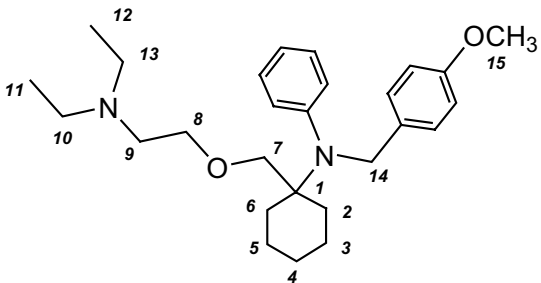

9k

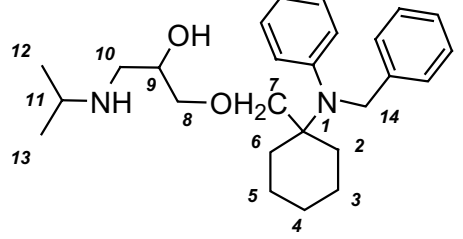

11a

\begin{tabular}{|c|c|c|}
\hline No. & Type & Data \\
\hline \multirow[b]{2}{*}{$5 c$} & ${ }^{1} \mathrm{HNMR}\left(\mathrm{CDCl}_{3}\right)$ & $\begin{array}{l}\text { 1.32-2.49 (m, } 10 \mathrm{H} \text {, cyclohexane); } 3.70(\mathrm{t}, 4 \mathrm{H}, J=4.75 \mathrm{H}-8,11) ; 3.92(\mathrm{t}, 4 \mathrm{H}, J= \\
\text { 4.77, } \mathbf{H - 9 , 1 0}) ; 7.15-7.26(\mathrm{~m}, 10 \mathrm{H}, \text { aromatic). }\end{array}$ \\
\hline & ${ }^{13} \mathrm{CNMR}\left(\mathrm{CDCl}_{3}\right)$ & $\begin{array}{l}22.97 \text { (C-3,5); } 25.20 \text { (C-4); } 33.17 \text { (C-2,6); } 45.35 \text { (C-8,11); } 58.33 \text { (C-1); } 66.87 \\
\text { (C-9,10); 127.81 (C-13,17); } 128.15 \text { (C-15); } 128.36 \text { (C-20-24); } 128.85 \text { (C-21,23) } \\
\text { 129.58(C-14,16); } 131.72 \text { (C-22); } 136.00 \text { (C-19); } 139.38 \text { (C-12); } 170.32 \text { (C-7) } \\
171.21 \text { (C-18). }\end{array}$ \\
\hline \multirow{2}{*}{$5 e$} & ${ }^{1} \mathrm{HNMR}\left(\mathrm{CDCl}_{3}\right)$ & $\begin{array}{l}\text { 1.45-2.10 (m, 10H, cyclohexane, H-9,10,11); } 3.32(\mathrm{t}, J=5.75,4 \mathrm{H}, \mathbf{H}-\mathbf{8}, \mathbf{1 2}) \\
\text { 7.10-7.92 (m, } 9 \mathrm{H} \text {, aromatic). }\end{array}$ \\
\hline & ${ }^{13} \mathrm{CNMR}\left(\mathrm{CDCl}_{3}\right)$ & 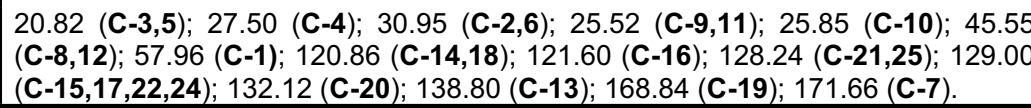 \\
\hline \multirow[b]{2}{*}{$5 g$} & ${ }^{1} \mathrm{HNMR}\left(\mathrm{CDCl}_{3}\right)$ & $\begin{array}{l}\text { 1.42-2.10 (m, 10H, cyclohexane, H-9,10); } 3.46(\mathrm{t}, \mathrm{J}=5.66,4 \mathrm{H}, \mathbf{H}-8,11) ; 3.74(\mathrm{~s}, \\
3 \mathrm{H}, \mathbf{H - 2 5}) ; 6.94-7.84(\mathrm{~m}, 9 \mathrm{H} \text {, aromatic). }\end{array}$ \\
\hline & ${ }^{13} \mathrm{CNMR}\left(\mathrm{CDCl}_{3}\right)$ & 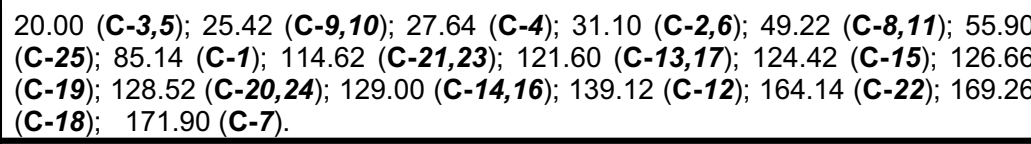 \\
\hline \multirow[b]{2}{*}{$6 a$} & $\begin{array}{l}{ }^{1} \mathrm{HNMR} \\
(\mathrm{DMSO}-\mathrm{D} 6)\end{array}$ & $\begin{array}{l}\text { 1.38-1.61 (m, 10H, cyclohexane, H-9,10); } 2.44(\mathrm{~m}, 4 \mathrm{H}, \mathbf{H}-\mathbf{8}, 11) ; 2.50(\mathrm{~s}, 2 \mathrm{H}, \mathbf{H}- \\
\text { 7); } 4.44(\mathrm{~s}, 2 \mathrm{H}, \mathbf{H}-18) ; 6.91-7.26(\mathrm{~m}, 10 \mathrm{H} \text {, aromatic). }\end{array}$ \\
\hline & $\begin{array}{l}{ }^{13} \mathrm{CNMR} \\
\left(\mathrm{DMSO}-\mathrm{D}_{6}\right)\end{array}$ & 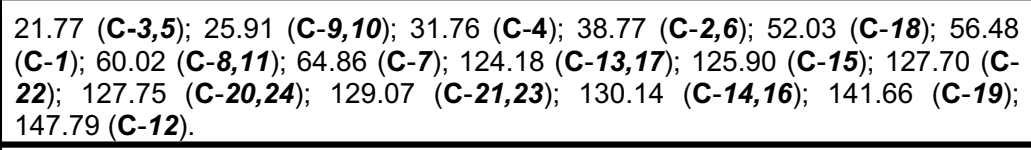 \\
\hline $6 e$ & $\begin{array}{l}{ }^{1} \mathrm{HNMR} \\
(\mathrm{DMSO}-\mathrm{D} 6)\end{array}$ & $\begin{array}{l}\text { 1.39-1.72 (m, 10H, cyclohexane, H-9,10,11); } 2.24 \text { (t, J }=6.24,4 \mathrm{H}, \mathbf{H}-\mathbf{8}, \mathbf{1 2}) ; 2.50 \\
(\mathrm{~s}, 2 \mathrm{H}, \mathbf{H}-\mathbf{7}) ; 4.62(\mathrm{~s}, 2 \mathrm{H}, \mathbf{H}-19) ; 6.58-7.20(\mathrm{~m}, 9 \mathrm{H} \text {, aromatic). }\end{array}$ \\
\hline
\end{tabular}




\begin{tabular}{|c|c|c|}
\hline & $\begin{array}{l}{ }^{13} \mathrm{CNMR} \\
\left(\mathrm{DMSO}-\mathrm{D}_{6}\right)\end{array}$ & 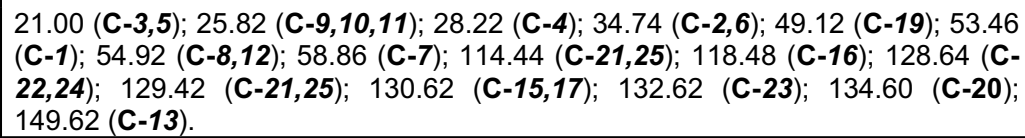 \\
\hline \multirow{2}{*}{$6 \mathbf{i}$} & $\begin{array}{l}{ }^{1} \mathrm{HNMR} \\
\text { (DMSO-D6) }\end{array}$ & $\begin{array}{l}\text { 1.38-1.76 (m, 10H, cyclohexane); } 2.38(\mathrm{t}, 4 \mathrm{H}, J=5.20 \mathrm{H}-8,11) ; 2.52(\mathrm{~s}, 2 \mathrm{H}, \mathrm{H}-7) \text {; } \\
3.68(\mathrm{t}, 4 \mathrm{H}, \mathrm{J}=5.56, \mathrm{H}-9,11) ; 3.72(\mathrm{~s}, 3 \mathrm{H}, \mathrm{H}-25) ; 4.62(\mathrm{~s}, 2 \mathrm{H}, \mathrm{H}-18) ; 6.68-7.20 \\
(\mathrm{~m}, 9 \mathrm{H}, \text { aromatic). }\end{array}$ \\
\hline & $\begin{array}{l}{ }^{13} \mathrm{CNMR} \\
\left(\mathrm{DMSO}-\mathrm{D}_{6}\right)\end{array}$ & $\begin{array}{l}21.20 \text { (C-3,5); } 28.42 \text { (C-4); } 34.82(\mathbf{C}-2,6) ; 49.22(\mathbf{C}-18) ; 53.62(\mathbf{C}-1) ; 54.24 \text { (C- }) \\
\text { 8,11); } 55.88 \text { (C-25); } 60.00 \text { (C-7); } 66.84 \text { (C-9,10); 114.10 (C-21,23); 114,90 (C- } \\
\text { 13,17); } 118.62 \text { (C-15); } 128.60 \text { (C-19); 129.24 ( C-20,24); } 130.36 \text { (C-14,16), } \\
149.60 \text { (C-12); } 159.20 \text { (C-22). }\end{array}$ \\
\hline $9 a$ & ${ }^{1} \mathrm{HNMR}\left(\mathrm{CDCl}_{3}\right)$ & $\begin{array}{l}1.22-1.80(\mathrm{~m}, 10 \mathrm{H}, \text { cyclohexane); } 3,64(\mathrm{~s}, 2 \mathrm{H}, \mathbf{H}-7) ; 4.61(\mathrm{~s}, 2 \mathrm{H}, \mathbf{H}-9) ; 4.71(\mathrm{~s} \text {, } \\
2 \mathrm{H}, \mathbf{H}-8) ; 7.01-7.56(\mathrm{~m}, 15 \mathrm{H} \text {, aromatic). }\end{array}$ \\
\hline \multirow[b]{2}{*}{$9 f$} & ${ }^{1} \mathrm{HNMR}\left(\mathrm{CDCl}_{3}\right)$ & $\begin{array}{l}\text { 1.38-1.74 (m, 10H, cyclohexane); } 2.72(\mathrm{t}, J=5.42,2 \mathrm{H}, \mathbf{H}-9), 3.52(\mathrm{~s}, 2 \mathrm{H}, \mathrm{H}-7) ; \\
3.74(\mathrm{t}, J=5.40,2 \mathrm{H}, \mathrm{H}-8) ; 4.62(\mathrm{~s}, 2 \mathrm{H}, \mathrm{H}-22) ; 6.85-7.20(\mathrm{~m}, 14 \mathrm{H} \text {, aromatic). }\end{array}$ \\
\hline & ${ }^{3} \mathrm{CNMR}\left(\mathrm{CDCl}_{3}\right)$ & $\begin{array}{l}21.40 \text { (C-3,5); } 28.20 \text { (C-4); } 33.42 \text { (C-2,6); } 36.22 \text { (C-9); } 49.36 \text { (C-22); } 54.50 \text { C-1); } \\
76.20 \text { (C-7); 76.86 (C-8); } 114.32 \text { (C-17,21); 118.46 (C-19); 126.00 (C-13); } \\
127.82 \text { (C-11,15); } 128.84 \text { (C-12,14); 129.60 (C-25,27); } 129.42 \text { (C-24,28); 130.20 } \\
(\mathbf{C}-18,20) ; 132.62 \text { (C-26); } 134.66 \text { (C-23); } 139.50 \text { (C-10); } 149.62 \text { (C-16). }\end{array}$ \\
\hline \multirow[b]{2}{*}{$9 \mathrm{~h}$} & ${ }^{1} \mathrm{HNMR}\left(\mathrm{CDCl}_{3}\right)$ & $\begin{array}{l}\text { 1.26-1.82 (m, 10H, cyclohexane); } 3.39(\mathrm{~s}, 2 \mathrm{H}, \mathrm{H}-7) ; 4.19 \quad(\mathrm{~s}, 2 \mathrm{H}, \mathrm{H}-27) ; 5.50(\mathrm{~s}, \\
1 \mathrm{H}, \mathbf{H}-8) ; 7.09-7.47(\mathrm{~m}, 19 \mathrm{H} \text {, aromatic). }\end{array}$ \\
\hline & ${ }^{13} \mathrm{CNMR}\left(\mathrm{CDCl}_{3}\right)$ & 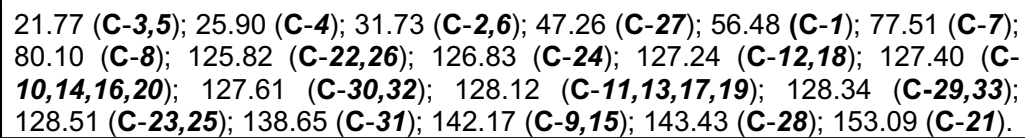 \\
\hline $9 k$ & ${ }^{1} \mathrm{HNMR}\left(\mathrm{CDCl}_{3}\right)$ & 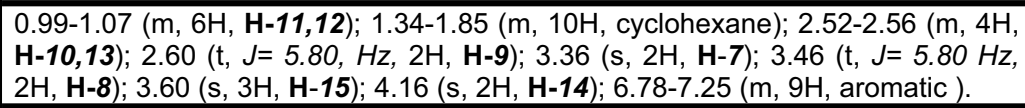 \\
\hline \multirow{2}{*}{$10 \mathrm{~b}$} & ${ }^{1} \mathrm{HNMR}\left(\mathrm{CDCl}_{3}\right)$ & $\begin{array}{l}\text { 1.37-1.74 (m, 10H, cyclohexane); 2.38, } 2.63(\mathrm{~d}, 2 \mathrm{H}, \mathbf{H}-10) ; 2.86(\mathrm{t}, 1 \mathrm{H}, \mathbf{H}-9) ; 3.52 \\
(\mathrm{~s}, 2 \mathrm{H}, \mathrm{H}-7) ; 3.38,3.63(\mathrm{~d}, 2 \mathrm{H}, \mathbf{H}-8) ; 4.61(\mathrm{~s}, 2 \mathrm{H}, \mathbf{H}-17) ; 6.85-7.24(\mathrm{~m}, 9 \mathrm{H} \text {, } \\
\text { aromatic). }\end{array}$ \\
\hline & ${ }^{13} \mathrm{CNMR}\left(\mathrm{CDCl}_{3}\right)$ & $\begin{array}{l}21.20 \text { (C-3,5); } 28.40 \text { (C-4); } 33.32 \text { (C-2,6); } 44.20(\mathbf{C}-10) ; 49.30(\mathbf{C}-17) ; 50.42 \text { (C- } \\
\text { 9); } 54.56 \text { (C-1); } 74.22 \text { (C-8); 75.84 (C-7); } 114.28 \text { (C-12,16); 118.62 (C-14); } \\
\text { 128.70 (C-20,22); } 129.42(\mathbf{C}-19,23) ; 130.00(\mathbf{C}-13,15) ; 132.60(\mathbf{C}-21) ; 134.60 \text { (C- } \\
\text { 18); } 149.64 \text { (C-11). }\end{array}$ \\
\hline $11 a$ & ${ }^{1} \mathrm{HNMR}\left(\mathrm{CDCl}_{3}\right)$ & 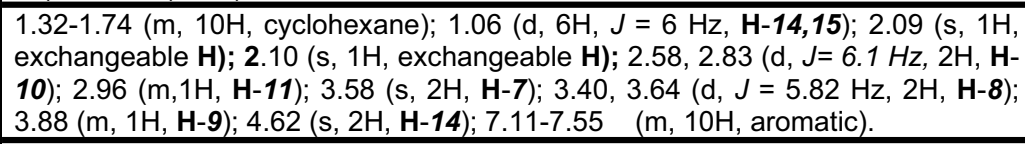 \\
\hline
\end{tabular}

* Arbitrary numbering is given to the compounds for ${ }^{1} \mathrm{H} \&{ }^{13} \mathrm{C}$ NMR data to facilitate the location of the specified atoms.

\section{Pharmacology}

All the tested compounds are used as bases suspended in $7 \%$ tween 80 and administered intraperitoneal 


\subsection{Determination of the anticonvulsant activity using maximal pentylenetetrazol seizures test [6]}

Experiments were carried out with two groups. The first group was divided into 5 subgroups (8 mice each) and received individually diphenylhydantoin sodium $(0.06,0.10$ and $0.20 \mathrm{mmol} / \mathrm{kg})$ as well as valproic acid $(0.17$ and $0.24 \mathrm{mmol} / \mathrm{kg})$ as reference standards. The second group was divided into 24 subgroups ( 8 mice each), each of which was injected with one of the tested compounds at the dose of $0.11 \mathrm{mmol} / \mathrm{kg}$ (c.f. Table 1). Two hours later [7] pentylenetetrazol $(90 \mathrm{mg} / \mathrm{kg}$ ) was administered intraperitoneal (i.p.). The survival rate was chosen as index for protective effects.

\subsection{Determination of lethal dose $50\left(L D_{50}\right)$ [8]}

The $L D_{50}$ of the most potent compounds among the series was determined using Behrens and Schlosser method. Groups of 5 animals each were used. The first group served as control and was injected i.p. with the corresponding volume of the vehicle ( $7 \%$ tween 80$)$. Other groups were injected i.p. with the tested compounds in doses ranging from $0.0525-0.650 \mathrm{mmol} / \mathrm{kg}$. Animals were observed and the mortality rates were recorded within the first 24 hours after compounds administration. The $\mathrm{LD}_{50}$ were determined according to the following formula:

$\mathrm{LD}_{50}=\mathrm{Dm}-\Sigma(\mathrm{z} \times \mathrm{d}) / \mathrm{n}, \quad$ where:

$\mathrm{Dm}=$ highest dose which kill all animals in the group .

$z=$ the mean of dead animals in two successive groups.

$d=$ the constant factor between two successive groups.

$\mathrm{n}=$ the number of animals in each of the dose levels.

\subsection{Determination of effective dose $50\left(E D_{50}\right)[9]$}

The $E D_{50}$ of the most potent compounds was statistically evaluated according to the method of Litchfield and Wilcoxo. 


\section{References}

[1] Mukhopadhyay S N, Bhrttacharya S K, Rao Y V, Das P K. A Study of the Anticonvulsant Activity of $\mathrm{N}$-Substituted Derivatives of 1 - Anilinocyclohexane Amide. Ind. J. Pharmnac. 1982; 14: 191-199.

[2] Aboul-Enein M N, El-Azzouny A A, Makhlouf A.A., Makld Y.A. Synthsis and Biological Evaluation of Certain N-Benzyl-N-(1Piperidine-1-yl-Cyclohexylmethyl)benzamides. Egypt. Pharm. J., NRC., 2004; 3: 19-34.

[3] Petts R L, Muspratt R, Plant S G P. Reactions of 1-Anilinocyclohexane-1-carboxylic acid. Synthesis of y-indoxylspirocyclohexane. J. Chem. Soc. 1927: 1310.

[4] Aboul-Enein M N, El-Difrawy S M, El-Azzouny A A, Nofal Z M Synthesis of 1,1-Disubstituted Cyclohexanes of Anticipated Analgesic and Local Anaesthetic Properties.

Egypt. J. Chem. 1982; 25: 573-8.

[5] Osa Y, Kobayashi S, Sato Y, Suzuki Y, Takino K, Takeuchi T, Miyata $Y$, Sakaguchi M, Takayanagi $H$.

Structural Properties of Dibenzosuberanylpiperazine Derivatives for Effieient Reversal of Chloroquine Resistance in Plasmodium chabaudi.

J. Med. Chem. 2003; 46: 1948-1956.

[6] Parmur S S, Gupta A K, Gupta T K, Stenberg V I.

Synthesis of Substituted Benzylidenehydrazines and Their Monoamine Oxidase Inhibitory and Anticonvulsant Properties J. Pharm. Sci. 1975; 64: 154.

[7] Hassert G L, Poutisiaka J W, Papandrianos D, Burke J C, Carver B V.

Pharmacological and Toxicological studies with 2-Amino-5-Phenyl1,3,4-Oxadiazole Hydrochloride.

Toxico. Appl. Pahrmacol. 1961; 3: 726-734.

[8] Behrns B, Schlosser L.

Determination of the Median Lethal Dose and Calculation of the Margin of Error

Arch. Exptl. Pathol. Pharmakol. 1957; 230: 59-72.

[9] Litchfield J T, Wilcoxon F.

Simplified Method of Evaluating Dose-Effect Experiments.

J. Pharmacol. Exp. Therap. 1949; 96: 99-113. 